\title{
Multilinguales
}

\section{Les langues et cultures étrangères dans les discours interactifs oraux et écrits}

Farida Boualit

\section{(2) OpenEdition}

1 Journals

Édition électronique

URL : http://journals.openedition.org/multilinguales/1548

DOI : $10.4000 /$ multilinguales. 1548

ISSN : 2335-1853

Éditeur

Université Abderrahmane Mira - Bejaia

Édition imprimée

Date de publication : 1 juin 2014

Pagination : 3

ISSN : 2335-1535

\section{Référence électronique}

Farida Boualit, "Les langues et cultures étrangères dans les discours interactifs oraux et écrits ", Multilinguales [En ligne], 3 | 2014, mis en ligne le 03 juin 2014, consulté le 25 septembre 2020. URL http://journals.openedition.org/multilinguales/1548; DOI : https://doi.org/10.4000/multilinguales. 1548

Ce document a été généré automatiquement le 25 septembre 2020.

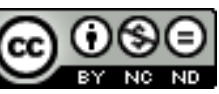

Multilinguales est mise à disposition selon les termes de la Licence Creative Commons Attribution Pas d'Utilisation Commerciale - Pas de Modification 4.0 International 
Les langues et cultures étrangères dans les discours interactifs oraux et écrits

Farida Boualit 
Longtemps maintenues séparées, la langue et la culture sont aujourd'hui envisagées dans leur étroite corrélation, et celle-ci fait l'objet d'une abondante littérature scientifique. Nul ne peut désormais faire fi de la définition de la langue comme " instrument de communication selon lequel l'expérience s'analyse, différemment dans chaque communauté, en unités... » (Martinet A., 1960). Ainsi, a-t-il été démontré que la langue, qui organise le réel, est un fait social inséparable de la culture. Cela devrait signifier, systématiquement, que l'on ne puisse pas appréhender une langue sans tenir compte de la culture qu'elle véhicule. Or, on constate que la langue, dans bien des situations, est confinée à un savoir-faire linguistique, en exclusion de son rapport à la culture, souvent bien problématique. En effet, l'équation langue/culture est complexe. Elle peut se décliner en « langue/culture », mais aussi en « langueS/culture », « langue/ cultureS », « langueS/cultureS ». Cette complexité est encore plus forte dans le cas des langues et des cultures étrangères au sein d'une communauté donnée, d'autant que ce sont le plus souvent les langues et les cultures des ex-colonisateurs. C'est la raison pour laquelle, ce couple langue/culture continue d'interpeller tous les spécialistes (mais pas seulement) qui tentent de comprendre l'impact des cultures sur la production/ compréhension des discours. En effet, qu'ils soient des sciences du langage, de la didactique des langues, des sciences des textes littéraires, de la traductologie, des chercheurs s'interrogent encore sur les rapports « langue/culture ", « discours/langue » dans leurs relations avec la culture. Multilinguales $\mathrm{N}^{\circ} 3$ s’y intéresse du point de vue des discours interactifs oraux et écrits dont l'analyse traiterait de ces interrogations-clés : qu'advient-il de la (des) culture(s) et de la (des) culture(s) étrangère (s), qu'advient-il de la (des) langue(s) et de la (des) langue(s) étrangère (s), quand il s'agit d'enseigner une langue (étrangère), d'écrire dans une langue (étrangère), de traduire dans une langue (étrangère), de converser dans une langue (étrangère), etc. ?

\section{AUTEUR}

\section{FARIDA BOUALIT}

Présidente du comité scientifique 